\title{
PENINGKATAN MOTIVASI BELAJAR MELALUI PEMBELAJARAN KOOPERATIF PADA MATA PELAJARAN KETERAMPILAN BOGA DI SMPN 2 GUGUAK KABUPATEN LIMA PULUH KOTA
}

\author{
Misnurina \\ SMPN 2 Guguak, Kecamatan Guguak, Kabupaten Lima Puluh Kota \\ email: misnurinainna@gmail.com
}

\begin{abstract}
The main objective of this action research is to improve 1) student learning motivation in the Culinary skills subject at SMPN 2 Guguak, 2) Student learning outcomes in the Culinary Skills subject at SMPN 2 Guguak. This type of research is Classroom Action Research (CAR). This classroom action research was conducted by following the model developed by Kemis and Mc Tanggar. The subjects of this study were students of class IX.3 of SMPN 2 Guguak who were taking food skills subjects of the 2017/2018 academic year. This research was conducted in the odd semester (semester 1) of the 2017/2018 academic year in the subject of Culinary Skills class IX 3 SMPN 2 Guguak, then continued in the second semester of the 2017/2018 academic year. This research was conducted in two cycles. The results showed that 1) there was an increasing in students' learning motivation in the Culinary skills subject at SMPN 2 Guguak, 2) there was an increase in student learning outcomes in the Culinary Skills subject at SMPN 2 Guguak.
\end{abstract}

Keywords: Learning Motivation, Cooperative Learning

\begin{abstract}
ABSTRAK
Tujuan utama dari penelitian tindakan ini adalah untuk meningkatkan 1) Motivasi belajar siswa pada mata pelajaran keterampilan Boga di SMPN 2 Guguak, 2) Hasil belajar siswa pada mata pelajaran Keterampilan Boga di SMPN 2 Guguak. Jenis penelitian ini adalah Penelitian Tindakan Kelas (PTK). Penelitian tindakan kelas ini dilakukan dengan mengikuti model yang dikembangkan oleh Kemis dan Mc Tanggar. Subjek penelitian ini adalah siswa kelas IX 3 SMPN 2 Guguak yang mengikuti mata pelajaran Keterampilan Boga tahun pelajaran 2017/2018. Penelitian ini dilakukan pada semester ganjil (semester 1) tahun ajaran 2017/2018 pada mata pelajaran Keterampilan Boga kelas IX 3 SMPN 2 Guguak, kemudian dilanjutkan pada semester 2 tahun ajaran 2017/2018. Penelitian ini dilaksanakan dalam dua siklus. Hasil penelitian menunjukkan bahwa 1) terjadi peningkatan Motivasi belajar siswa pada mata pelajaran keterampilan Boga di SMPN 2 Guguak, 2) terjadi peningkatan Hasil belajar siswa pada mata pelajaran Keterampilan Boga di SMPN 2 Guguak.
\end{abstract}

Kata kunci: Motivasi Belajar, Pembelajaran Kooperatif

\section{PENDAHULUAN}

Paradigma lama mengenai proses belajar mengajar bersumber pada teori tabula rasa John Locke, (Asma, 2001:1) menyatakan bahwa pikiran seorang anak adalah seperti kertas kosong yang putih dan siap menunggu coretan-coretan gurunya. Dengan kata lain otak seorang anak adalah ibarat botol kosong yang siap 
diisi dengan segala ilmu pengetahuan dan kebijaksanaan guru. Menurut Lie (2002:2-3), "Banyak guru melaksanakan kegiatan belajar mengajar dengan cara memindahkan pengetahuan dari guru ke siswa, siswa adalah penerima pengetahuan yang pasif, mengkotak-kotakkan siswa, serta memacu siswa dalam kompetisi".

Tuntutan dalam dunia pendidikan sudah banyak berubah, guru tidak bisa lagi mempertahankan paradigma lama tersebut. Telah banyak teori, penelitian, dan pelaksanaan kegiatan pembelajaran yang membuktikan bahwa para guru sudah harus mengubah paradigma pengajaran. Daya upaya untuk meningkatkan kualitas proses dan hasil pendidikan senantiasa dicari, dipikirkan, dan diteliti melalui komponen pendidikan dan kesemuanya merupakan usaha nyata pemerintah dan masyarakat untuk mencerdaskan dan meningkatkan sumber daya manusia Indonesia.

Dalam konteks teknologi pendidikan proses belajar mengajar terjadi apabila peserta didik berinteraksi dengan lingkungan belajar yang ditata oleh guru. Di lain pihak proses pembelajaran yang efektif menentukan pendaya gunaan berbagai usaha dan prasarana yang optimal, berorientasi pada peserta didik, serta penggunaan strategi pembelajaran yang sesuai. Kenyataan menunjukkan bahwa kegiatan pembelajaran sebagian besar masih bersifat "teachers centered" atau strategi yang terpusat pada guru. Metode yang digunakan dalam konteks klasikal pada umumnya menggunakan kombinasi ceramah dan tanya jawab.

Kurikulum SMP sekarang ini terdiri dari kurikulum Nasional dan kurikulum Muatan Lokal. Kurikulum Nasional cakupannya untuk seluruh wilayah Indonesia, sedangkan kurikulum Muatan Lokal diserahkan kebijaksanaan pada daerah masing-masing, bahkan materi pelajaran sekarang ini diserahkan kebijaksanaannya pada sekolah masing-masing.

SMP Negeri 2 Guguak yang merupakan salah satu SMP Negeri yang termasuk dalam wilayah Kabupaten Lima Puluh Kota memilih mata pelajaran keterampilan boga untuk kurikulum Muatan Lokal. Pada mata pelajaran Keterampilan Boga ini siswa diberikan ilmu pengetahuan dan berbagai macam keterampilan yang berguna untuk meningkatkan pengetahuan dan keterampilan.

Hilgar dalam Sanjaya (2006:110) menyatakan bahwa belajar adalah proses perubahan melalui kegiatan atau prosedur latihan baik di dalam laboratorium maupun dalam lingkungan alamiah. Selanjutnya Dimyati (1992:27) berpendapat bahwa pembelajaran adalah suatu kegiatan guru secara terprogram dalam disain instruksional, untuk membuat siswa belajar secara aktif yang menekankan pada penyediaan sumber belajar. Tetapi dalam melaksanakan proses pembelajaran selama ini peneliti memakai metode ceramah, tanya jawab, dan pemberian tugas. Menurut hasil pengamatan peneliti selama mengajar peneliti melihat bahwa mata pelajaran Keterampilan Boga ini kurang diminati oleh siswa di sekolah peneliti. Hal ini terlihat dari kurangnya perhatian siswa dalam mengikuti pelajaran, siswa sering minta izin, dan siswa banyak yang tidak mempunyai catatan. Kemudian siswa sulit untuk memahami konsep yang diajarkan, ini dibuktikan lebih kurang $60 \%$ siswa disekolah penulis memperoleh nilai ujian akhir dibawah nilai ketuntasan belajar minimal yang ditetapkan di sekolah penulis. Nilai ketuntasan belajar individual yang ditetapkan sekolah penulis adalah 65 .

Di samping itu rendahnya minat dan hasil belajar siswa pada mata pelajaran Keterampilan Boga menurut peneliti disebabkan oleh karena mata 
pelajaran tersebut tidak dimasukkan pada penentuan kelulusan siswa. Serta kurangnya sarana dan prasarana yang mendukung dalam melaksanakan proses pembelajaran di sekolah penulis. Sardiman (2007:75) menjelaskan bahwa dalam kegiatan belajar motivasi dapat dikatakan sebagai keseluruhan daya penggerak di dalam diri siswa yang menimbulkan kegiatan belajar mengajar, yang menjamin kelangsungan dari kegiatan belajar dan memberikan arah pada kegiatan belajar, sehingga tujuan dapat dicapai.

Untuk mengatasi masalah-masalah pada pembelajaran Keterampilan Boga di sekolah penulis, penulis mencoba mendiskusikan dengan sesama guru mata pelajaran maka diambil suatu kesimpulan bahwa untuk meningkatkan minat dan hasil belajar siswa pada mata pelajaran Keterampilan Boga, terlebih dahulu siswa harus termotivasi dalam belajar. Siswa akan berhasil dalam belajar, kalau pada dirinya sendiri ada keinginan atau motivasi untuk belajar.

Dalam hal ini dilakukan penelitian tindakan kelas (action research), dengan menerapkan pembelajaran kooperatif (cooperative learning). Berdasarkan uraian di atas, maka penulis akan mengadakan penelitian dengan judul peningkatan motivasi belajar melalui pembelajaran kooperatif pada mata pelajaran Keterampilan Boga di SMPN 2 Guguak Kabupaten Lima Puluh Kota.

\section{METODOLOGI}

Jenis penelitian ini adalah Penelitian Tindakan Kelas (PTK). Penelitian tindakan kelas ini dilakukan dengan mengikuti model yang dikembangkan oleh Kemis dan Mc Tanggar dalam Arikunto (2006:117) "Suatu siklus spiral yang terdiri dari empat komponen yaitu 1) rencana atau planning merupakan tahap awal yang harus dilakukan yaitu membuat rencana tindakan untuk perbaikan mutu atau pemecahan masalah; 2) tindakan atau action merupakan implementasi tindakan sesuai dengan yang telah direncanakan; 3) observasi (observation) yaitu melakukan pengamatan terhadap efek dari tindakan yang diberikan untuk melihat dan mendokumentasikan pengaruh-pengaruh yang diakibatkan oleh tindakan tersebut, hasil pengamatan merupakan dasar untuk melakukan refleksi; 4) refleksi (reflection) melakukan kegiatan analisis dan sintesis penafsiran, menjelaskan, dan menyimpulkan”. Dari hasil refleksi diadakan revisi terhadap perencanaan yang digunakan untuk perbaikan pada siklus berikutnya.

Subjek penelitian ini adalah peneliti sendiri, dan siswa kelas IX SMPN 2 Guguak yang mengikuti mata pelajaran Keterampilan Boga. Penelitian ini dilakukan pada semester ganjil (semester 1) tahun ajaran 2017/2018 pada mata pelajaran keterampilan boga kelas IX 3 SMPN 2 Guguak, kemudian dilanjutkan pada semester 2 tahun ajaran 2017/2018. Penelitian ini dilaksanakan dalam dua siklus. Instrumen yang digunakan dalam penelitian ini yaitu angket dan lembar pengamatan.

\section{HASIL PENELITIAN DAN PEMBAHASAN}

\section{Hasil Penelitian.}

\section{Hasil Penelitian Siklus Pertama}

1. Pelaksanan Kegiatan

Pelaksanan kegiatan pada siklus pertama sesuai dengan yang telah direncanakan yaitu: 
a. Pada pertemuan pertama membagi siswa 5 kelompok yang beranggotakan 4 orang tiap kelompok yang nama-nama kelompok di ambil dari nama buahbuahan

b. Setiap kelompok menyebutkan nama kelompok beserta anggota

c. Membagi wacana materi yang akan didiskusikan, tiap kelompok mendapat tugas yang berbeda

d. Kegiatan berikutnya dilanjutkan dengan kegiatan setiap siswa diharuskan membaca dan mencari informasi serta mendiskusikan materi pada kelompok masing-masing yang akan dipresentasikan setelah diskusi kelompok

e. Pada kegiatan berikutnya mempresentasikan hasil kelompok dan memberi kesempatan bertanya dan menanggapi hasil kelompok yang di paparkan dan hasil presentasi dikumpulkan

f. Kertas kerja kelompok dikumpulkan dan guru memberi nilai

g. Pada pertemuan berikutnya siswa sudah mulai aktif dan mengerti belajar kelompok serta berdiskusi dimana ada peningkatan motivasi siswa dalam bertanya dan menanggapi materi yang didiskusikan

h. Pada setiap kegiatan yang dikemukakan diatas observer mengamati dan mencatat motivasi siswa dengan menggunakan lembar observasi yang telah disediakan.

i. Pada akhir siklus pertama diadakan pengisian angket yang di isi oleh siswa dan wawancara kepada beberapa orang siswa

Pembelajaran yang diikuti oleh 20 orang siswa pada siklus pertama ini dilakukan selama 3 minggu dengan pokok bahasan pengetahuan bahan makanan, pada akhir pertemuan dikumpulkan hasil resume diskusi tiap-tiap kelompok.

2. Data dan Analisis Data siklus pertama

a. Hasil Observasi Motivasi Siswa

Data yang diperoleh pada siklus pertama tentang motivasi siswa dalam mata pelajaran Keterampilan Boga pada 3 kali pertemuan yang dilakukan dapat dilihat pada Tabel1.

Tabel 1. Persentase Hasil Motivasi Siswa Pada Siklus Pertama

\begin{tabular}{|c|c|c|c|c|c|c|c|c|}
\hline \multirow[t]{3}{*}{ No } & \multirow{3}{*}{$\begin{array}{l}\text { Motivasi } \\
\text { yang } \\
\text { diamati }\end{array}$} & \multicolumn{6}{|c|}{ Pertemuan ke } & \multirow{3}{*}{$\begin{array}{c}\text { Rata- } \\
\text { rata }\end{array}$} \\
\hline & & \multicolumn{2}{|r|}{1} & \multicolumn{2}{|c|}{2} & \multicolumn{2}{|r|}{1} & \\
\hline & & $\mathbf{f}$ & $\%$ & $\mathbf{F}$ & $\%$ & $\mathbf{F}$ & $\%$ & \\
\hline 1 & $\begin{array}{l}\text { Motivasi } \\
\text { mencari } \\
\text { invormasi }\end{array}$ & 11 & $55 \%$ & 13 & $65 \%$ & 16 & $80 \%$ & $66,7 \%$ \\
\hline 2 & $\begin{array}{l}\text { Motivasi } \\
\text { bertanya/me } \\
\text { nang-gapi }\end{array}$ & 12 & $60 \%$ & 14 & $70 \%$ & 15 & $75 \%$ & $68,3 \%$ \\
\hline 3 & Kerja sama & 13 & $65 \%$ & 15 & $75 \%$ & 17 & $85 \%$ & $75 \%$ \\
\hline 4 & $\begin{array}{l}\text { Penilaian } \\
\text { hasil } \\
\text { belajar }\end{array}$ & & $72,7 \%$ & & $76,3 \%$ & & $79,2 \%$ & $76,1 \%$ \\
\hline
\end{tabular}

Persentase hasil pengamatan untuk setiap motivasi yang diamati pada perencana dapat dilihat hasil sebagai berikut: 
1) Motivasi yang paling banyak muncul adalah motivasi untuk bekerja sama dimana untuk setiap pertemuan persentasenya selalu naik, sudah tergolong baik karena sudah mencapai persentase rata-ratanya $75 \%$ siswa melakukan motivasi ini.

2) Motivasi berikutnya juga banyak nampak dan tergolong baik adalah motivasi untuk bertanya dan menanggapi, dimana setiap pertemuan cenderung naik dan siswa melakukan motivasi tersebut dengan persentase rata-ratanya $68,3 \%$

3) Motivasi siswa mencari informasi setiap pertemuan juga mengalami kenaikan dimana rata-rata persentasenya $66,7 \%$.

4) Penilaian hasil belajar siswa tiap pertemuan mengalami kenaikan dan tergolong baik karena sudah melebihi dari $75 \%$, dimana rata-rata persentasenya $76,1 \%$.

b. Hasil Catatan Lapangan Siklus Pertama

Data catatan lapangan yang diperoleh dapat dilihat pada Tabel 2 sebagai berikut :

Tabel 2. Hasil Catatan Lapangan Siklus Pertama

\begin{tabular}{|c|c|c|}
\hline Hal-hal yang dicatat & Kekurangan dan Alasan & $\begin{array}{c}\text { Upaya perbaikan yang } \\
\text { dilakukan }\end{array}$ \\
\hline Penyajian guru & $\begin{array}{c}\text { Setting duduk kelompok } \\
\text { kurang teratur, materi } \\
\text { diperbanyak di bagi } \\
\text { kepada siswa }\end{array}$ & $\begin{array}{c}\text { Diatur setting duduk } \\
\text { kelompok siswa, } \\
\text { materi dicopi dan } \\
\text { diperbanyak }\end{array}$ \\
\hline Kegiatan diskusi & $\begin{array}{c}\text { Tidak semua siswa aktif } \\
\text { diskusi kelompok }\end{array}$ & $\begin{array}{c}\text { Peneliti dan observer } \\
\text { mendatangi siswa } \\
\text { yang kurang aktif }\end{array}$ \\
\hline Kehadiran siswa & $\begin{array}{c}\text { Masih ada siswa yang } \\
\text { ingin permisi keluar } \\
\text { selama diskusi }\end{array}$ & $\begin{array}{c}\text { Diberi toleransi } \\
\text { hanya 2 orang } \\
\text { selama diskusi }\end{array}$ \\
\hline
\end{tabular}

c. Hasil Angket Siswa

Sehubungan dengan angket terbuka dengan seluruh siswa di kelas IX 3, diperoleh persepsi siswa secara umum tentang metode pembelajaran secara Kooperatif hasil tersebut dapat dilihat pada Tabel 3.

T abel 3. Hasil Angket Siswa

\begin{tabular}{|l|l|c|c|c|c|}
\hline NO & \multicolumn{1}{|c|}{ PERNYATAAN } & SS & S & KS & TS \\
\hline 1 & $\begin{array}{l}\text { Saya senang mengikuti } \\
\text { pelajaran Keterampilan Boga } \\
\text { Saya selalu memperhatikan } \\
\text { keterangan guru dan tanggapan } \\
\text { guru }\end{array}$ & 8 & 11 & 1 & - \\
\hline 3 & $\begin{array}{l}\text { Saya akan mengajukan } \\
\text { pertanyan bila ada yang saya } \\
\text { tidak mengerti dalam belajar } \\
\text { Saya mempelajari buku paket } \\
\text { Pengetahuan Bahan dan } \\
\text { makanan sebelum belajar }\end{array}$ & 2 & 7 & 11 & - \\
\hline 4 & $\begin{array}{l}\text { Saya akan menjawab pertanyaan } \\
\text { yang diajukan oleh guru dan }\end{array}$ & 2 & 15 & 3 & - \\
\hline 5
\end{tabular}




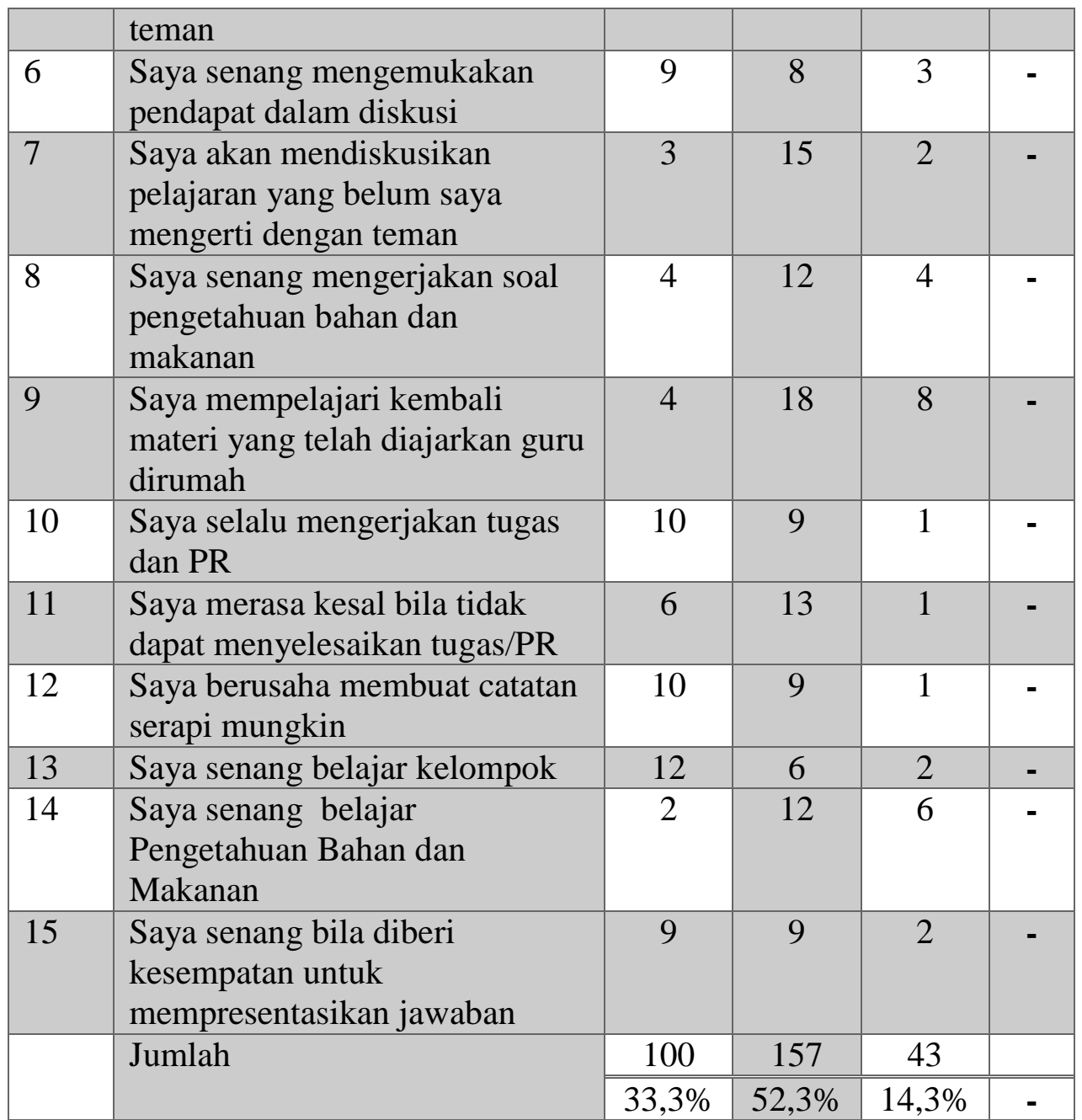

Berdasarkan Tabel 3 dapat digambarkan bahwa hasil angket siswa pada umumnya siswa senang mengikuti pelajaran Keterampilan Boga dengan metode kooperatif, yang menyatakan senang (S) dan sangat senang (SS) sudah tergolong baik dimana jumlah persentase keduanya adalah $85,6 \%$.

d. Hasil Wawancara dengan Siswa

Hasil wawancara dengan beberapa orang siswa yang dipilih secara acak, diperoleh persepsi bahwa siswa secara umum senang belajar dengan menggunakan metode Kooperatif, karena para siswa dapat mengemukakan pendapat sendiri dan menyampaikan gagasan sesuai dengan kemampuan yang dimiliki siswa, hal ini dapat dilihat pada Tabel 1 dimana persentase rata-rata bertanya $68,3 \%$.

3. Analisis Refleksi

Dari data hasil pengamatan observasi catatan lapangan, angket terbuka serta wawancara, akan dianalisis untuk mendapatkan refleksi yang akan digunakan pada pelaksanaan siklus selanjutnya. Dari hasil observasi selama kegiatan pembelajaran berlansung pada siklus pertama diperoleh gambaran bahwa motivasi siswa mulai tampak pada siklus pertama. Terdapat beberapa temuan yang memuaskan yaitu : 
a. Motivasi mencari informasi untuk didiskusikan dalam kelompok sudah sangat baik karena pada pertemuan I persentasenya tercatat $55 \%$ dan terus cenderung naik hingga pertemuan 3 sudah mencapai $80 \%$.

b. Motivasi untuk bertanya/menanggapi juga selalu tampak naik dimana pertemuan 1 persentasenya $60 \%$ dan pertemuan 3 sudah mencapai $75 \%$.

c. Kerja kelompok juga mengalami kenaikan dimana persentasenya $65 \%$ pada pertemuan 1 menjadi $75 \%$ pada pertemuan 3 .

Hasil refleksi yaitu sebagai berikut:

a. Sebagian anggota kelompok, dalam berdiskusi siswa belum bisa menahan diri, siswa tidak dapat memfungsikan moderator, mereka ingin menjawab pertanyaan atau menanggapi secara langsung/spontan.

b. Siswa yang tidak aktif disebabkan karena tidak diberikan/belum ada kesempatan diberikan oleh teman-teman kelompok.

c. Siswa kurang percaya diri, malu-malu untuk bertanya.

\section{Hasil Penelitian Siklus Kedua}

1. Perenungan berdasarkan siklus pertama

Dari hasil refleksi pada siklus pertama, masih ada hal-hal yang dianggap perlu dilakukan perbaikan, atas dasar tersebut maka pelaksanan penelitian perlu dilanjutkan pada siklus kedua, hal-hal yang perlu diperbaiki adalah sebagai berikut :

a. Motivasi untuk mencari informasi masih memperlihatkan hasil yang belum memuaskan dimana persentase rata-rata hanya $66,7 \%$ yang melakukan aktivitas ini, maka pada siklus kedua diberi kesempatan untuk mengumpulkan buku pegangan sebanyak mungkin.

b. Motivasi kerjasama dalam diskusi kelompok juga masih belum memuaskan dimana persentase rata-rata hanya $75 \%$ yang melakukan aktivitas ini, maka pada siklus kedua diberikan kesempatan untuk membentuk kelompok pada siswa sendiri untuk memilih temannya.

c. Siswa yang sering minta izin keluar didekati dan diharapkan berkurang jumlahnya. Secara garis besar perencanaan dan pelaksanaan siklus kedua tidak jauh berbeda dengan siklus pertama. Perbaikan yang dilakukan tidak menambah urutan pelaksanannya, yang dilakukan hanyalah perbaikan kebijakan yang diprediksi akan dapat meningkatkan motivasi dan penguasaan materi dalam pembelajaran keterampilan Boga.

2. Data dan analisis data siklus ke dua.

a. Hasil observasi motivasi siswa

Data hasil observasi yang diperoleh pada siklus kedua mengenai motivasi siswa dalam pelaksanaan pembelajaran keterampilan boga dapat dilihat pada Tabel 4 berikut:

Tabel.4. Proses Hasil Pengamatan Motivasi Siswa Pada Siklus Kedua.

\begin{tabular}{|l|l|c|c|c|c|c|c|l|}
\hline \multirow{2}{*}{ No } & \multirow{2}{*}{$\begin{array}{l}\text { Motivasi yang } \\
\text { diamati }\end{array}$} & \multicolumn{6}{|c|}{ Pertemuan ke } & \multirow{2}{*}{$\begin{array}{l}\text { Rata- } \\
\text { rata }\end{array}$} \\
\cline { 3 - 10 } & & \multicolumn{2}{|c|}{$\mathbf{1}$} & \multicolumn{2}{|c|}{$\mathbf{2}$} & \multicolumn{2}{|c|}{$\mathbf{3}$} & \\
\hline $\mathbf{1}$ & $\begin{array}{l}\text { Motivasi } \\
\text { mencari } \\
\text { informasi }\end{array}$ & 16 & $80 \%$ & 17 & $85 \%$ & 18 & $90 \%$ & $\mathbf{8 5 \%}$ \\
\hline $\mathbf{2}$ & Motivasi & 16 & $80 \%$ & 18 & $90 \%$ & 19 & $95 \%$ & $\mathbf{8 8 , 3 \%}$ \\
\hline
\end{tabular}




\begin{tabular}{|l|l|l|l|l|l|l|l|l|}
\hline & $\begin{array}{l}\text { bertanya/mena } \\
\text { nggapi }\end{array}$ & & & & & & & \\
\hline $\mathbf{3}$ & Kerja sama & 17 & $85 \%$ & 18 & $90 \%$ & 18 & $90 \%$ & $\mathbf{8 8 , 3 \%}$ \\
\hline $\mathbf{4}$ & $\begin{array}{l}\text { Penilaian } \\
\text { hasil belajar }\end{array}$ & & $\begin{array}{l}\mathbf{8 2 , 7} \\
\mathbf{\%}\end{array}$ & & $\mathbf{8 5 \%}$ & & $\begin{array}{l}\mathbf{8 6 , 8} \\
\mathbf{\%}\end{array}$ & $\mathbf{8 4 , 8 \%}$ \\
\hline
\end{tabular}

Dari tabel 4 dapat dilihat motivasi siswa pada siklus kedua ini adalah tergolong baik karena sudah lebih dari $75 \%$ rata-rata keberhasilan yang dicapai yaitu :

1) Motivasi untuk mencari invormasi pada siklus kedua ini tergolong baik, dengan persentase rata-rata $85 \%$.

2) Motivasi bertanya/menanggapi sangat baik karena dapat dilihat perbandingan rata-rata persentase siklus pertama dan persentase pada silkus kedua, hal ini disebabkan pada siklus kedua siswa sudah mulai percaya diri dan suadah punya keberanian.

3) Kerja sama pada siklus kedua ini juga baik dimana rata-rata persentasenya menjadi $88,3 \%$.

4) Penilaian hasil belajar juga terjadi kenaikan, rata-rata persentasenya dari $82,7 \%$ menjadi $84,8 \%$.

b. Hasil catatan lapangan siklus kedua

Hasil catatan lapangan siklus kedua ini dapat dilihat tabel 5.

Tabel.5. Hasil Catatan Lapangan Siklus Kedua

\begin{tabular}{|l|l|l|}
\hline \multicolumn{1}{|c|}{$\begin{array}{c}\text { Hal-hal yang } \\
\text { dicatat }\end{array}$} & Kekurangan dan Alasan & $\begin{array}{c}\text { Upaya perbaikan yang } \\
\text { dilakukan }\end{array}$ \\
\hline Penyajian guru & $\begin{array}{l}\text { Penyajian materi agak } \\
\text { tergesa-gesa, karena } \\
\text { diburu waktu }\end{array}$ & $\begin{array}{l}\text { Menjelaskan konsep } \\
\text { materi agar dapat } \\
\text { dibahas }\end{array}$ \\
\hline Kegiatan diskusi & $\begin{array}{l}\text { Masih terdapat siswa } \\
\text { yang kurang aktif dalam } \\
\text { diskusi kelompok }\end{array}$ & $\begin{array}{l}\text { Peneliti dan observer } \\
\text { membimbing siswa } \\
\text { yang kurang aktif }\end{array}$ \\
\hline Kehadiran siswa & $\begin{array}{l}\text { Masih ada siswa yang } \\
\text { permisi keluar selama } \\
\text { diskusi berlansung }\end{array}$ & $\begin{array}{l}\text { Diberi toleransi hanya } \\
\text { untuk keperluan yang } \\
\text { penting }\end{array}$ \\
\hline
\end{tabular}

Hasil angket terbuka siswa format angket terbuka yang digunakan pada siklus pertama, masih dipakai pada siklus kedua, hasil dari angket terbuka siswa dapat dilihat pada Tabel 6 berikut.

Tabel.6. Hasil Angket Siswa Pada Siklus Kedua

\begin{tabular}{|l|l|c|c|c|c|}
\hline NO & \multicolumn{1}{|c|}{ PERNYATAAN } & SS & S & KS & TS \\
\hline 1 & $\begin{array}{l}\text { Saya senang mengikuti pelajaran } \\
\text { Keterampilan Boga }\end{array}$ & 7 & 12 & 1 & - \\
\hline 2 & $\begin{array}{l}\text { Saya selalu memperhatikan } \\
\text { keterangan guru dan tanggapan guru }\end{array}$ & 9 & 10 & 1 & - \\
\hline 3 & $\begin{array}{l}\text { Saya akan mengajukan pertanyan } \\
\text { bila ada yang saya tidak mengerti } \\
\text { dalam belajar }\end{array}$ & 8 & 10 & 2 & - \\
\hline 4 & $\begin{array}{l}\text { Saya mempelajari buku paket } \\
\text { Pengetahuan Bahan dan makanan } \\
\text { sebelum belajar }\end{array}$ & 2 & 8 & 10 & - \\
\hline
\end{tabular}




\begin{tabular}{|c|c|c|c|c|c|}
\hline 5 & $\begin{array}{l}\text { Saya akan menjawab pertanyaan } \\
\text { yang diajukan oleh guru dan teman }\end{array}$ & 3 & 16 & 1 & - \\
\hline 6 & $\begin{array}{l}\text { Saya senang mengemukakan } \\
\text { pendapat dalam diskusi }\end{array}$ & 8 & 9 & 3 & - \\
\hline 7 & $\begin{array}{l}\text { Saya akan mendiskusikan pelajaran } \\
\text { yang belum saya mengerti dengan } \\
\text { teman }\end{array}$ & 3 & 15 & 2 & - \\
\hline 8 & $\begin{array}{l}\text { Saya senang mengerjakan soal } \\
\text { pengetahuan bahan dan makanan }\end{array}$ & 5 & 13 & 2 & - \\
\hline 9 & $\begin{array}{l}\text { Saya mempelajari kembali materi } \\
\text { yang telah diajarkan guru dirumah }\end{array}$ & 10 & 9 & 1 & - \\
\hline 10 & $\begin{array}{l}\text { Saya selalu mengerjakan tugas dan } \\
\text { PR }\end{array}$ & 8 & 10 & 2 & - \\
\hline 11 & $\begin{array}{l}\text { Saya merasa kesal bila tidak dapat } \\
\text { menyelesaikan tugas/PR }\end{array}$ & 6 & 13 & 1 & - \\
\hline 12 & $\begin{array}{l}\text { Saya berusaha membuat catatan } \\
\text { serapi mungkin }\end{array}$ & 10 & 9 & 1 & - \\
\hline 13 & Saya senang belajar kelompok & 13 & 6 & 1 & - \\
\hline 14 & $\begin{array}{l}\text { Saya senang belajar Pengetahuan } \\
\text { Bahan dan Makanan }\end{array}$ & 2 & 13 & 5 & - \\
\hline 15 & $\begin{array}{l}\text { Saya senang bila diberi kesempatan } \\
\text { untuk mempresentasikan jawaban }\end{array}$ & 9 & 9 & 2 & - \\
\hline & \multirow[t]{2}{*}{ Jumlah } & 103 & 162 & 35 & \\
\hline & & $34 \%$ & $54 \%$ & $11,6 \%$ & - \\
\hline
\end{tabular}

Dari hasil angket terbuka siswa pada siklus kedua ini dapat digambarkan kemajuan, bahwa pada umumnya siswa masih termotivasi untuk belajar keterampilan Boga dengan metode kooperatif.

c. Hasil wawancara dengan siswa

Pada siklus kedua ini peneliti tidak lagi melaksanakan wawancara karena hasil diskusi/hasil belajar kelompok sudah baik dimana hasil diskusi/hasil belajar kelompok persentasenya sudah mencapai $85 \%$.

3. Analisis refleksi

Setelah mengkaji kembali tindakan penelitian pada siklus kedua terdapat beberapa hal yang perlu peneliti kemukakan :

a. Motivasi siswa pada siklus kedua ini hasilnya sangat memuaskan sekali dimana sudah melebihi target yang diharapkan yaitu diatas $75 \%$ keberhasilannya.

b. Motivasi untuk mencari informasi pada siklus kedua ini mengalami kenaikan dimana rata-rata persentasenya $85 \%$, Motivasi untuk bertanya/menanggapi mencapai $88,3 \%$, sedangkan kerja sama atau diskusi kelompok juga naik menjadi $88,3 \%$.

c. Penguaasan materi juga digambarkan dengan hasil diskusi, rata-rata persentase keberhasilannya naik yaitu $84,8 \%$

\section{PEMBAHASAN}

Berdasarkan hasil analisis data pada siklus pertama, beberapa hal yang merupakan dampak positif yang muncul sebagai konsekwensi dan penerapan model kooperatif dalam pembelajaran Keterampilan Boga sangat membantu siswa 
dalam memahami materi sehingga motivasi siswa sangat tinggi. Diskusi kelompok kecil dalam kegiatan belajar dirasakan sangat bermanfaat oleh siswa, mereka merasakan lebih akrab dengan teman dan merasa dekat dengan guru, serta mereka mempunyai kesempatan bertanya yang lebih luas untuk memahami materi.

Dengan pembelajaran kooperatif, hasil kerja siswa dapat diselesaikan dengan baik, meskipun belum semua siswa dapat menyelesaikan dengan sempurna, menyebabkan hasil yang dicapai pada siklus pertama belum maksimal.

1. Belum memuaskan hasil pada siklus pertama maka dilakukan perbaikan pada siklus kedua, pada siklus kedua nampak peningkatan motivasi siswa

2. Semua kegiatan telah tuntas dicapai oleh siswa pada siklus kedua. Dengan adanya kenaikan pencapaian materi/ hasil diskusi berarti siswa sudah dikatakan menguasai materi pelajaran.

Kenaikan penguasaan materi pelajaran oleh siswa disebabkan perlakuan yang diberikan pada metode pembelajaran yang diterapkan, terutama dengan menerapkan metode kooperatif, disini nampak meningkatnya cara berpikir anak dan siswa lebih percaya diri. Walaupun peningkatan motivasi dan penguasan materi secara umum sudah meningkat, namun masih ada beberapa aspek yang masih belum memuaskan, diantaranya kegiatan dalam diskusi kelompok masih ada siswa yang tidak aktif memberikan pendapat, walaupun sudah diberi motivasi, hal ini mungkin disebabkan masih kurang berani dan kurang percaya diri, dan juga keberadaan siswa dikelas masih belum memuaskan karena masih ada siswa yang minta izin keluar pada saat diskusi berlangsung.

\section{KESIMPULAN DAN SARAN}

Hasil penelitian menunjukkan bahwa 1) terjadi peningkatan Motivasi belajar siswa pada mata pelajaran keterampilan Boga di SMPN 2 Guguak, 2) terjadi peningkatan Hasil belajar siswa pada mata pelajaran Keterampilan Boga di SMPN 2 Guguak.

Dari hasil temuan yang dicapai, dan beberapa hal yang belum memuaskan dan perlu ditindak lanjuti, maka disarankan :

1. Motivasi mencari informasi, keluar minta izin selama diskusi, masih ada yang belum aktif, maka hal ini perlu menjadi perhatian, dengan demikian perlu tindak lanjuti dan di sarankan mengadakan penelitian lanjutan dengan metode kooperatif.

2. Guru dalam meningkatkan motivasi pembelajaran di sarankan agar menggunakan metode kooperatif.

3. Penelitian tindakan kelas dengan menerapkan metode Kooperatif agar dapat dilanjutkan oleh kelompok mata pelajaran yang lain.

\section{DAFTAR PUSTAKA}

Arikunto, Suharsimi dkk. 2006. Penelitian Tindakan Kelas. Jakarta: PT Bumi Aksara

Asma, Nur. 2006. Model Pembelajaran Kooperatif. Jakarta: Departemen Pendidikan Nasional

Dimyati, dkk. 1999. Belajar dan Pembelajaran. Jakarta: PT Rineka Cipta.

Lie, Anita. 2002. Cooperative Learning: Mempraktekkan Cooperative Learning di Ruang-Ruang Kelas. Jakarta: Grasindo. 
Sanjaya, Wina. 2006. Strategi Pembelajaran Berorientasi Standar Proses Pendidikan. Jakarta : Fajar Interpratama offset.

Sardiman A.M. 2007. Interaksi dan Motivasi Belajar Mengajar. Jakarta: PT Raja Grafindo Persada. 